\title{
Pola Pembelajaran Science di Prasekolah
}

\author{
Chintia Eka Putri ${ }^{1}$, Sugito $^{2}$ \\ Pendidikan Anak Usia Dini, Universitas Negeri Yogyakarta, Indonesia(1) \\ DOI: $\underline{10.31004 / o b s e s i . v 6 i 2.1571}$
}

\begin{abstract}
Abstrak
Pembelajaran sains selama ini dipandang sebagai suatu pembelajaran yang menyulitkan dan memerlukan banyak bahan serta pengetahuan yang cukup luas sehingga masih sangat perlu dicari pola implementasinya. Tujuan penelitian ini adalah mengkaji tentang pola pembelajaran Science yang berkembang di Prasekolah. Metode yang digunakan ialah penelitian kualitatif yang bersifat studi pustaka. Jenis analisis yaitu deskriptif kualitatif melalui proses telaah literatur yang berasal dari penelusuran database jurnal nasional dan internasional. Artikel kemudian diambil melalui seleksi dengan kriteria tertentu. Lima belas artikel ilmiah memenuhi kriteria yaitu : (a) Fokus di model pembelajaran sains(b)Hasil stimulasi (c)Anak usia dini. Hasil penelitian menunjukkan bahwa ada dua pola pembelajaran sains yang sering diterapkan yaitu pola pembelajaran direct dan indirect. Selain itu pembelajaran sains efektif untuk menstimulasi perkembangan pada tiga ranah utama yaitu kognitif, psikomotorik dan afektif.
\end{abstract}

Kata Kunci : pembelajaran; sains; anak usia dini; stimulasi

\begin{abstract}
Science learning has been seen as a difficult learning and requires a lot of materials and knowledge that is quite broad so it is still very necessary to look for patterns of implementation. The purpose of this study is to examine the pattern of science learning that develops in Preschooler. The method used is a qualitative research that is literature study. The type of analysis is descriptive qualitative through a literature review process that comes from searching national and international journal databases. Articles are then taken through a selection with certain criteria. Fiveteen scientific articles meet the criteria, namely: (a) focus on science learning models (b) Stimulation results (c) early childhood. The results showed that there are two patterns of science learning that are often applied, namely direct and indirect learning patterns. In addition, science learning is effective in stimulating development in three main areas, namely cognitive, psychomotor and affective.
\end{abstract}

Keywords: learning; science; early childhood; stimulation

Copyright (c) 2021 Chintia Eka Putri, Sugito

$\triangle$ Corresponding author:

Email Address : chintia.official@gmail.com (Yogyakarta, Indonesia)

Received 23 February 2021, Accepted 23 July 2021, Published 31 July 2021 


\section{PENDAHULUAN}

Di abad ke 21, laju perkembangan ilmu pengetahuan dan teknologi sangat akan pesat. Dunia akan dipenuhi produk-produk hasil penyelidikan ilmiah, dan manusia menggunakan informasi ilmiah sebagai pertimbangan untuk menentukan pilihan pada berbagai situasi yang dihadapi setiap harinya. Pada saat itu, Setiap orang dituntut berani mengambil peran dalam isu-isu penting yang melibatkan sains dan teknologi serta cerdas dalam memilih alternatif solusi. Hasil Analisis Programme for International Student Asessment menempatkan Indonesia pada peringkat 71 dengan skor 397 pada sains (OECD, 2018). Hal senada juga disampaikan oleh Menteri Pendidikan Dan kebudayaan Nadiem Anwar Makarim bahwa hasil PISA tersebut menjadi evaluasi berharga sekaligus acuan pemerintah untuk membenahi kualitas pendidikan 5 tahun kedepan dengan berfokus pada kompetensi yang harus dimiliki peserta didik dalam menghadapi abad 21 (Tohir, 2019).

Salah satu cara untuk meningkatkan kualitas pendidikan Indonesia yaitu memperkenalkan literasi sains sedini mungkin sejak jenjang prasekolah. Banyak persoalan yang akan muncul di masa mendatang seperti krisis air bersih, pengendalian penyakit, energi yang terbatas hingga perubahan iklim, untuk itu kunci utama dalam menghadapi tantangan abad ke-21 adalah Science (UNEP, 2012). Maka dari itu science dikategorikan emergent topic in early childhood education yang artinyaharus dikenalkan sedini mungkin (Noor, 2020). Sebab penting sekali membangun dasar pemahaman ilmiah sedini mungkin agar terbentuklah pola pikir, keterampilan-keterampilan penting serta sikap peduli dan tanggung jawab pada diri sendiri, masyarakat, dan persoalan lingkungan hidup secara global pada anak.

Pembelajaran sains selama ini dipandang sebagai suatu pembelajaran yang menyulitkan dan memerlukan banyak bahan serta pengetahuan yang cukup luas. Apalagi pengetahuan tentang sains sangat dekat dengan Ilmu pengetahuan Alam (IPA). Guru PAUD lebih menginginkan pembelajaran yang tidak memerlukan banyak penalaran dan sesuai dengan kondisi anak yang masih belum mampu menalar lebih jauh (Rahmah, 2019). Pandangan lain dari beberapa guru bahwa pembelajaran sains dapat menghabiskan waktu belajar yang lain sehingga pembelajaran sains tidak dapat dilihat hasilnya, berbeda dengan fisik motorik.

Pengetahuan guru terhadap pembelajaran sains masih rendah sehingga kurang diminati dan anak tidak memperoleh banyak pengalaman tentang sains. Dan masih kurangnya kreativitas guru dalam menerapkan pembelajaran sains, sehingga media yang akan digunakan dirasakan sulit untuk diperoleh. Masih ada terdapat persepsi negative tentang pembelajaran sains dan belum merasa perlu, dikarenakan anak setelah masuk sekolah dasar akan mempelajari juga (Rahmah, 2019). Serta pola pikir guru masih memandang penting pembelajaran lainnya dibandingkan dengan pembelajaran sains itu sendiri.

Penelitian lain Yunansah (2014)menyebutkan bahwa sains diterjemahkan sebagai materi ajar yang memang tidak dibelajarkan secara mendalam di TK. Namun bukan berarti anak dilarang mempelajarinya. Oleh sebab itu untuk membuat pembelajaran sains di TK tidak menyulitkan, lebih bermakna dan bersahabat tentu perlu pengemasan (packaging) pembelajaran yang interaktif dan holistik. Sebenarnya, disadari atau tidak, konsep sains telah anak pelajari secara otodidak. Namun, umumnya anak kurang menyadari bahwa yang sedang dipahaminya merupakan konten sains.

Kemampuan anak dalam memahami konsep sains menjadi bagian yang terpenting dalam pembelajaran sains. Pemahaman konsep sains pada anak usia dini mengandung makna yang sangat sederhana, karena pembelajaran sains yang dimaksud bukanlah berisi rumus ataupun teori. Sehingga dalam praktiknya anak hanya membutuhkan suatu objek nyata yang dapat diamati kemudian mencari tahu sebab akibat dari peristiwa tersebut dengan membangun pemahamannya berdasarkan pengetahuan dan pengalaman sebelumnya (Zulaiha \& Rohman, 2020).

Selain itu sains menjadi hal yang penting kerena berorientasi pada terbentuknya pemahaman dan pengakuan atas kekuatan pemikiran dan pembelajaran awal di Taman 
kanak-kanak. Menyisipkan pembelajaran sains pada praktik pengajaran di lingkup pendidikan anak usia dini menjadi sorotan karena anak-anak merespon sesuatu sesuai usianya, memaknai semuanya sebagai permainan. Dengan suasana bermain (learning by playing) memerlukan strategi yang integratif agar pembelajaran sains tidak dinilai sebagai suatu pemaksaan bagi anak untuk mampu memahami dan menguasai konsep sains sebagai syarat berkembangnya keterampilan akademik tanpa memperdulikan taraf perkembangan anak (Saepudin, A :2011). Kebutuhan untuk fokus pada sains permulaan didasarkan pada sejumlah faktor yang melatarbelakagi. Pertama dan terpenting yaitu Science merupakan suatu pendekatan pembelajaran yg masih baru khususnya di jenjang Taman Kanak-Kanak sehingga masih perlu dicari pola pembelajaran yang paling tepat untuk mengimplementasikan pembelajaran science sesuai kaidah perkembangan anak usia dini. Hanya sedikit penelitian yang membahas secara komprehensif keterampilan apa saja yang terbangun ketika anak mempelajari konsep sains ilmiah selain keterampilan kognitif.

Tinjauan ini difokuskan pada konteks pembelajaran sains dan menyelidiki pertanyaan penellitian (a) bagaimana pola pembelajaran sains yang diterapkan di taman kanak kanak?(b) Komponen pembelajaran sains apa yang secara eksplisit diidentifikasi sebagai hal penting untuk pembelajaran di taman kanak-kanak?(c) Aspek perkembangan apa saja yang bisa di stimulasi melalui pembelajaran sains anak usia dini?

Pembahasan mengenai pola pembelajaran sains anak usia dini dalam konteks tinjauan pustaka dianggap penting atas dasar perlunya paradigma yang utuh mengenai pembelajaran sains yang efektif diterapkan di taman kanak-kanak. Sehingga perlunya pengajaran yang tepat agar selama proses sains, seluruh aspek perkembangan anak dapat terstimulasi dengan optimal dan seimbang. Meskipun dalam istilahnya sains sebagai model pembelajaran yang berorientasi pada perkembangan kognitif.

\section{METODOLOGI}

Dalam Kajian Penelitian ini, penulis menggunakan pendekatan kualitatif bersifat studi pustaka. Teknik yang dipakai oleh penulis ialah literatur review dengan tahapantahapan meliputi pencarian teori dan referensi kepustakaan yang relevan dengan topik permasalahan yang peneliti kaji. Literatur review ialah sebuah teknik penelitian dengan proses menelaah berbagai kajian sumber kepustakaan menjadi sebuah sintesis yang diperlukan dalam bahasan penelitian (Nazir, 2014). Sumber kepustakaan tersebut berhubungan dengan perkembangan anak usia dini dan pembelajaran sains di Prasekolah.

Peneliti melaksanakan literature review dengan mengkaji berbagai referensi dari jurnal nasional dan didukung oleh jurnal internasional. Literatur yang dikumpulkan yaitu berupa jurnal nasional tahun 2011-2021. Melalui penelusuran medeley tersaring 200 kajian yang peneliti temukan dengan kata kunci pembelajaran sains dan perkembangan anak usia dini. Namun setelah dilakukan skrining dengan kriteria Jurnal Terakreditasi Sinta 1, 2 , dan 3 hanya diperoleh 13 kajian yang memenuhi kriteria yang ditentukan peneliti. Skema literature review digambarkan seperti diagram pada gambar 1 . Untuk melakukan tinjauan sistematis literatur, penulis mengikuti pendekatan yang mirip dengan yang dibahas oleh(Bennett, 2016). Data dianalis menggunakan teknik kualitatif dengan metode desktriptif sehingga memperoleh hasil secara mendalam, terperinci dan detail.

Tinjauan sistematis ini berfokus pada artikel jurnal telaah sejawat. Dalam pendekatan ini, Pencarian awal kami (1) mengembangkan kriteria/topik strategi pencarian dengan mengidentifikasi beberapa artikel ilmiah terpublikasi di Jurnal SINTA yang berfokus pada pola-pola penerapan pembelajaran sains dan hasil stimulasi yang terkait dengan aspek perkembangan siswa di tingkat pra-taman kanak-kanak (2) mencari artikel yang memenuhi kriteria kami, (3) menyaring artikel untuk memastikan mereka memenuhi kriteria untuk dimasukkan, dan (4) mengelompokkan literatur yang diperoleh (5) mengekstrak rincian yang dilaporkan dari aspek-aspek spesifik dari studi dan terakhir menarik kesimpulan. Dan 
mengidentifikasi dua jurnal internasional sebagai tambahan untuk memperkuaat telaah dan hasil analisis.

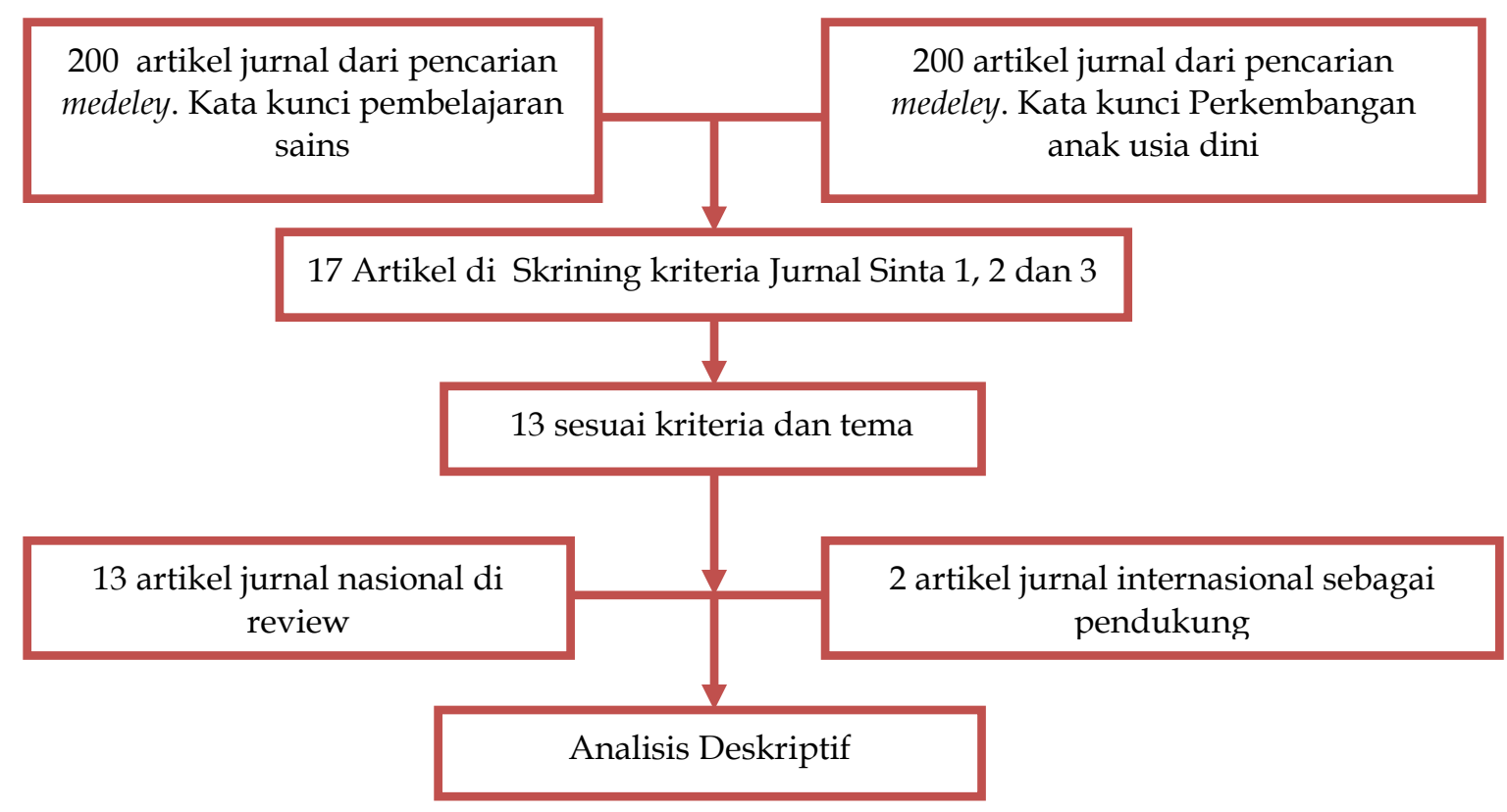

Gambar 1. Skema Literatur Review

\section{HASIL DAN PEMBAHASAN}

\section{Pola Pembelajaran Sains di Taman Kanak-Kanak}

Golden age merupakan masa cemerlang yang pasti lalui semua anak. Pada masa ini pertumbuhan dan perkembangan fisik, emosional, sosial serta intelektual melaju sangat pesat. Perkembangan dinilai sebagai pola perubahan manusia yang dimulai sejak masa pembuahan sampai berkelanjutan. Pola perubahan ini terjadi sepanjang usia manusia akibat dari kematangan fisik dan psikis serta pengalaman belajar yang berlangsung secara progresif. ((Santrock, 2007);(Hurlock, 2000)). Oleh karena itu penting sekali optimalisasi stimulasi pada potensi yang dimiliki oleh anak melalui pemberian intervensi melalui pembelajaran yang sesuai dengan tahap perkembangan anak.

Pembelajaran sains di taman kanak-kanak dirancang secara sistematis melalui pola tertentu sehingga memberikan kemudahan cara mengukurnya. Pola pembelajaran diartikan sebagai satu faktor yang penting dan sangat berpengaruh terhadap prestasi atau hasil belajar yang diperoleh siswa. Sebab dalam pendidikan diketahui bahwa siswa mempunyai pola belajar yang berbeda antara satu dengan yang lainnya (Nugraha, 2008). Sains di taman kanakkanak terdiri dari segala kegiatan pengamatan langsung yang dilakuakan anak-anak untuk menumbuhkan minat dan pemahan tentang alam melalui interaksi sosial secara perlahanlahan (Broström, 2015).

Hasil dari analisis literatur ditemukan ada dua Pola pembelajaran sains yang berkembang di taman kanak-kanak. Pola tersebut diidentifikasi sebagai pola direct dan indirect. Pola tersebut dielaborasikan dengan berbagai metode pengajaran seperti eksperimen/percobaan, bermain, demonstrasi, praktik langsung, tanya jawab dan berkelompok. Dari ke dua pola pembelajaran sains, pola pembelajaran guru dan media dalam aktivitas eksperimen atau percobaan terbimbing menjadi yang paling kerap dilaksanakan di Taman Kanak-Kanak, diikuti oleh demontrasi dalam pengajaran sains. Kemudian aktivitas sains melalui bermain, pengamatan/ penyelidikan. Dan yang paling jarang dilakukan ialah aktivitas menyelesaikan masalah sendiri tanpa bantuan guru. Untuk melihat uraian literatur 
yang telah direview dan dianalisis untuk menjaring pola pembelajaran yang digunakan dapat di lihat di tabel 1 (lampiran 1).

Pola pembelajaran direct instructional digambarkan sebagai pembelajaran guru dalam menyajikan pembelajaran sains denganciri pengajaran yaitu penjelasan langsung dari guru berkaitan dengan konsep dan keterampilan baru yang akan dipelajari. Model pengajaran ini melibatkan interaksi antar guru dan siswa secara individual ataupun dalam pembelajaran kelompok (Watanabe et al., 2013) model ini berfokus pada capaian target yang menjadi tujuan pengajaran sehingga segala bentuk stimulasi dikaitkan dengan target yang dituju misalnya melalui pelatihan-pelatihan keterampilan (Aufan, 2011) sebuah pendekatan cara mengajar yang bersifat teacher center atau berpusat pada guru (Trianto 2012). Pola ini terdiri dari lima tahap aktivitas yakni orientasi, presentasi, praktik yang terstruktur, praktik di bawah bimbingan, dan praktik mandiri (Joyce, 2009). Namun pola ini memiliki kelemahan yaitu Kesempatan untuk mengontrol pemahaman siswa akan materi pembelajaran sangat terbatas pula disamping itu. Komunikasi satu arah bisa mengakibatkan pengetahuan yang dimiliki siswa akan terbatas pada apa yang diberikan (Sanjaya, 2007). Sehingga pemhaman abstrak anak tidak terbangun menjadi pemahaman konkret yang utuh. Misalnya menceritakan tentang gunung meletus secara abstrak dalam metode ceramah namun tidak memberi dukungan dalam bentuk gambar/ video, miniatur gunung ataupun media lainnya.

Pola pembelajaran indirect instructional menjadi satu kebaharuan dimana ekplorasi anak menjadi lebih konkret dan keterbatasan guru dalam memaparkan fenomena-fenomena sains diminimalisir. Pola ini merupakan kebalikan dari pola pembelajaran langsung, karena siswa memperoleh informasi dengan sendirinya, guru hanya membimbingnya. Oleh karena itu, kegiatan pembelajarannya lebih banyak berpusat kepada siswa (student centered). Strategi pembelajaran tak langsung sering dikaitkan dengan model pembelajaran inquiry, model discovery learning, problem solving models, pengambilan keputusan, dan scientific learning method. Hal ini berbeda dengan strategi direct instructional atau pembelajaran langsung, dimana jenis pembelajaran ini menjadikan guru sebagai centernya. Indirect menjadikan anak sebagai aktor utama pembelajar. Anak yang menyelidik, guru hanya sebagai fasilitator dan menyediakan lingkungan belajar yang kondusif serta kesempatan luas bagi anak untuk terlibat dalam segala bentuk kegiatan.

Beberapa media yang digunakan guru berhubungan dengan kegiatan sains sensori yang dilakukan menggunakan media-media terdekat anak. Seperti media air, pewarna makanan, tumbuh-tumbuhan, bahan-bahan dapur dan media lainnya. Temuan penelitian (Smolleck, 2011) mengenaipenyelidikan dan kesalahan konsep sains pada anak usia dini dan mengungkapkan bahwa intervensi terbaikyang dipakaianak untuk membentuk pemahaman tentang sains adalah dengan cara memberi kesempatan secara langsung untuk mengeksplorasi unsur-unsur sains yang sedang dipelajari. Guru hanya fasilitator. Anak yang memulai eksplorasinya tanpa di kawal. Setelah bereksplorasi guru akan memancing pertanyaan divergen untuk mengarahkan anak pada pembelajarannya. Misalnya, menggunakan "sentuhan" untuk mengidentifikasi kasar dan halus melalui indera peraba dan kategorisasi "dapat diminum dan tidak dapat diminum" untuk membedakan apakah zat yang sedang diamati tersebut memiliki wujud cair atau padat. Berikutnya ialah ketika proses eksperimen sedang berlangsung, anak secara bernangsur-angsur dan konsisten mengintegrasikan pengetahuan dan pengalaman yang mereka dapat sebelumnya untuk membahasakan pengetahuan baru yang mereka peroleh.

Oleh sebab itu, pengetahuan dan pengalaman yang anak alami sebelumnya menjadi pijakan bagi anak ketika mengembangkan konsep baru sehingga perlu adanya identifkasi awal untuk menilai sejauh apa konsep sains yang anak dapatkan sebelumnya. Hal serupa dipaparkan juga dalam hasil penelitian lain yang mengatakan bahwa konten sains hendaknya didasarkan pada fenomen-fenomena yang diamati dan dialami anak secara langsung dalam kehidupannya sehari-hari (Guo et al.,2015). Maknanya, semua hal yang akan dipelajari anak 
haruslah dimulai dari konten-konten terdekat anak yang bersifat konkret khususnya pada pengayaan pembelajaran sains.

Pada konteks pembelajaran di PAUD, strategi pembelajaran yang akan diterapkan dibebaskan pada masing-masing guru. Berdasarkan hasi temuan penelitian Veny Iswantiningtyas dkk dalam Tatminingsih (2019) menjelaskan sebuah rutinitas yang dilakukan dalam kegiatan pembelajaran umumnya diawali sapaan, nyanyian, membahas tema, dan apersepsi tentang topik. Lalu kemudian anak bermain di beberapa area main yang disiapkan oleh guru. Selanjutnya dibagian penutup, pembelajaran diakhiri dengan kegiatan recallingdengan cara memberikan kesempatan kepada semua anak untuk menceritakan pengalaman main yang dirasakan secara bergiliran bisa dengan tanya jawab ataupun bercerita didepan kelas.

Selain dielaborasikan dengan metode eksperimen, Tinjauan pustaka pada lima belas jurnal ditemukan pula bahwa pola pembelajaran sains dimuat dalam berbagai mixing implementation seperti (1) pembelajaran sains melalui quantum learning models yang mengusung konsep Tumbuhkan, Alami, Namai, Ulangi dan Rayakan (TANDUR) (Dewi et al., 2019) (2) Pembelajaran sains melalui permainan sensori motorik(Fardiah et al., 2019) (3) Pembelajaran sains menggunakan Bermain APE (Widayati et al., 2020) (4) Pembelajaran sains melalui inquiry approach (Howitt et al., 2011) (5) Pembelajaran sains dengan dicovery method (Magasida, 2017)(6)pembelajaran sains melalui playing based learning(Levy, 2013)(7) sains melalui process skill approach(Nirmala, 2014) (8) Sains melalui pengamatan fenomena fisika(Poppyariyana \& Munajat, 2020) (9) pembelajaran sains menggunakan metode open ended question dan pemberian tugas (Witarsa \& Dista, 2019)hingga (10) sains menggunakan pendekatan situasional, terpisah dan terintegrasi (Yunansah, 2014). Representasi diatas bermuara pada penerapan pembelajaran sains yang dinamis di taman kanak-kanak dan menghadirkan interaksi anak dan guru melalui media eksplorasi selama proses pembelajaran berlangsung.

Pembelajaran sains untuk anak usia dini berorientasi pada pembelajaran yang bersifat konkret seperti melalui kegiatan langsung dengan materi sebab akibat, sehingga anak memiliki kesempatan untuk eksplorasi, mengkonstruksi pengetahuan sendiri serta mendapatkan pengalaman yang bermakna. Anak distimulasi untuk bertanya menggunakan kata "apa" dan menjawab berbagai persoalan yang disajikan guru. Namun jarang guru yang mampu memancing anak untuk bertanya menggunakan kata "mengapa". Tipe pengajaran sains di prasekolah juga lebih menekankan pada proses daripada produk, memungkinkan menggunakan bahasa dan matematika, pengenalan sains terpadu, dan bidang ilmu lainnya dengan lebih menarik.

\section{Komponen Utama Sains untuk Mengoptimalisasi Proses Stimulasi Anak}

Sains merupakan suatu "badan pengetahuan tentang benda-benda si alam yang diperoleh dengan cara tertentu. Sains mulai dengan fakta dan berakhir dengan fakta." Dimana fakta menjadi tolak ukur pembuktian sains. Kemampuan anak membangun konsep sains menjadi bagian terpenting dalam pembelajaran sains. Pemahaman konsep sains untuk anak usia dini bukanlah berisi rumus ataupun teori melainkan mengandung makna yang sangat sederhana. Pada praktiknya, sebetulnya anak hanya membutuhkan objek nyata yang dapat diamati untuk kemudian dicari tahu sebab akibat dari peristiwa tersebut, lalu selanjutnya anak mengkonstruk sendiri pengetahuan dan pengalaman sebelumnya untuk membangun pengetahuan baru (Zulaiha \& Rohman, 2020). Dari hasil analisis literatur riview diperoleh 3 komponen utama sains sebagai stimulasi perkembangan anak sebagai berikut :

\section{Sensory motorik dan panca indera}

Temuan peneliti bahwa kegiatan yang menstimulasi sensori motorik dan panca indera banyak dilakukan dalam kegiatan sains khususnya pada kegiatan eksperimen. Hasil persentase penggunaan indera dalam uraian literatur bisa dilihat pada Gambar 2. 

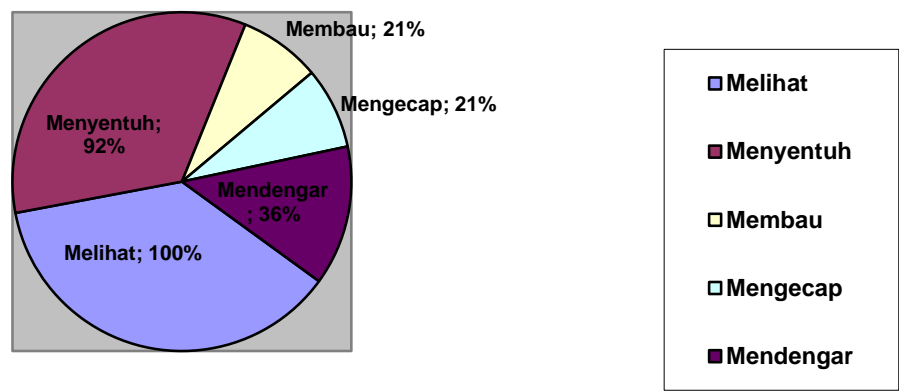

Gambar 2. Intensitas penggunaan Indera

Diagram pada gambar 2 menjelaskan bahwa dari lima belas literatur yang direview, semua aktivitas sains yang dilakukan paling banyak menggunakan indera mata untuk melihat kemudian diikuti oleh menyentuh atau meraba media yang diamati, dan yang paling masih jarang dilakukan ialah membau dan mengecap. Pemanfaatan indera ini screening awal anak sebagai penanda keingintahuannya yang kemudian membentuk banyak pertanyaan di otak anak. Lima panca indera ini distimulasi dalam kegiatan observasi. Hal ini didukung penelitian Smolleck (2011) bahwa anak sebetulnya memulai eksplorasinya tanpa di kawal. Setelah bereksplorasi guru akan memancing pertanyaan divergen untuk mengarahkan anak pada pembelajarannya. Misalnya, menggunakan "sentuhan" untuk mengidentifikasi kasar dan halus melalui indera peraba dan kategorisasi "dapat diminum dan tidak dapat diminum" untuk menentukan apakah suatu zat yang diamati tersebut memiliki wujud cair atau padat.Indera merupakan screening pertama yang dilakukan anak ketika dihadapkan pada hal-hal baru. Indera ini memiliki peranan penting dalam perkembangan anak dalam membangun pengetahuannya melalui yang dilihat, dirasa, didengar, diraba, dan juga dicium melalui panca indra yang dimilikinya.

\section{Bermain melalui media}

Dunia anak dunia bermain. Segala sesuatu yang dilakukan tanpa paksaan akan memberi pengalaman bermakna. Apalagi jika dalam bermain terdapat muatan pembelajaran sains, seperti bermain fisika membuat pelangi dari pantulan cahaya, eksperimen gunung meletus, benda tenggelam dan terapung dan lain sebagainya. Salah satu penelitian menyebutkan bermain dapat memberikan anak kesempatan luas untuk belajar, bereksplorasi, berkreasi, mengamati, menemukan, dan mengekspresikan perasaan dengan menyenangkan (Rahmawati, 2018). Selain menyenangkan, seluruh aspek perkembangan anak terstimulasi dengan optimal. Karena mood yang baik akan memberikan feedback terbaik untuk pertumbuhan dan perkembangan. Sebarang alat permainan edukatif yang digunakan dapat dilihat pada gambar 3 .

Pemanfaatan alat permainan edukatif memiliki dampak yang besar untuk menyelesaikan tugas anak. Media edukatif ini dijadikan sarana guru untuk memancing anak terlibat aktif dalam pembelajaran. benda padat, mengenal gerak benda, mengenal benda cair, mengenal sifat terapung dan tenggelam, mengenal warna, mengenal benda elastis, mengenal udara, mengenal bayang-bayang, mengenal neraca, mengenal api, mengenal es, mengenal bunyi, serta mengenal benda magnet. Melalui bermain terbentuknya motivasi dan minat anak bahwa belajar itu menyenang dan anak dapat menuntaskan tugas-tugas perkembangannya dengan bimbinganorang-orang terdekatnya. 


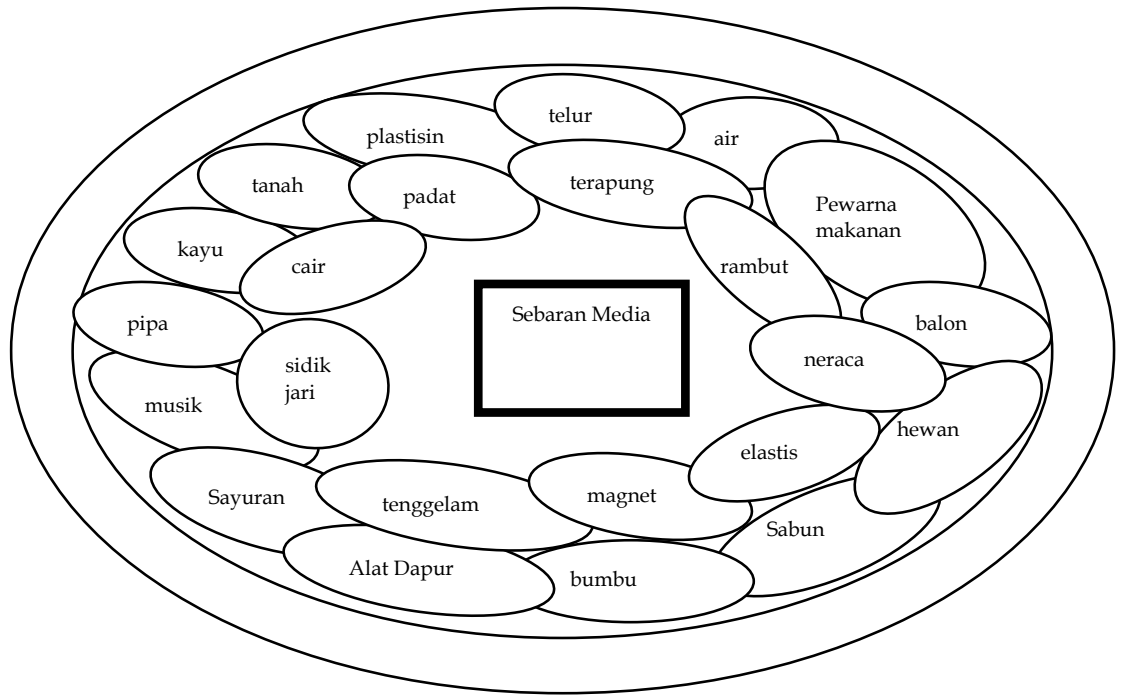

Gambar 3. Sebaran Alat Permainan Edukatif yang Digunakan

\section{Materi pembelajaran dekat dengan kehidupan sehari-hari}

Menurut Vygotsky dalam (Adbo \& Carulla, 2020) Anak usia dini mengembangkan literasi sains mereka melalui dua tahapan, (1) Konsep sehari-hari atau yang disebut dengan hasil interaksi dari aktivitas sehari-hari di lingkungan keluarganya sehingga terbentuklahpengetahuan dan pengalaman dalam kehidupan sehari-harinya, dan (2) konsep saintifik (ilmiah), yaitu konsep yang diperoleh anak melalui akademis di sekolah. Kedua kosep tersebut saling mempengaruhi. Dimana konsep sehari-hari sebagai peletak dasar untuk mempelajari konsep saintifik. Oleh karena itu penting adanya pengayaan dari guru untuk memfasilitasi pemahaman konsep anak di sekolah melalui pembelajaran sains, karena saat melakukan eksperimen anak memiliki kesempatan untuk mengaplikasikan serta mengaitkan konsep-konsep baru yang telah ia peroleh ke dalam situasi kehidupan sehari-hari. Sehingga menghasilkan kemampuan anak dalam mengenal informasi baru, membangun pemahaman, dan mampu menjelaskan hubungan antar fenomena ilmiah yang terjadi dengan bahasa mereka sendiri(Widiyatmoko \& Shimizu, 2018).

Berdasarkan penjelasan tersebut maka pembelajaran sainsdapat dijadikan sebagai intervensi untuk perkembangan anak usia dini. Intervensi inilah yang mampu meningkatkan perkembangan pemerolehan nilai-nilai dan moral anak, perkembangan motorik, kognitif, bahasa, sosial-emosional anak usia dini. Meski erat kaitanya dengan kegiatan eksplorasi dengan media dan panca indera. Bentuk stimulasi ini dapat meningkatkan tiga ranah kognitif, ranah afektif dan ranah psikomotorik anak sehingga mempengaruhi pertumbuhan dan perkembangan anak secara optimal.

\section{Hasil Stimulasi Perkembangan Anak Pada Pembelajaran Sains}

Pada poin pembahasan ini menjelaskan mengenai hasil stimulasi perkembangan anak pada pembelajaran sains berdasarkan temuan beberapa hasil penelitian yang menggambarkan pembelajaran sains memiliki pengaruh terhadap perkembangan anak usia dini. Ada tiga ranah pada hasil stimulasi dalam taksonomi bloom meliputi:

\section{Ranah Kognitif}

Teori Piaget menyebutkan bahwa perkembangan kognitif terdiri dari 4 tahapan yaitu tahap sensori motor (lahir - 2 tahun) diikuti pra-operasional (usia 2-7 tahun) selanjutnya tahap operasional konkret (usia 7-11 tahun) dan terakhir tahap operasional formal (usia 11-15 tahun). Pada tiap tahapan terdapat masing-masing tugas perkembangan yang harus dituntaskan. Periode bagi anak usia dini ialah di 2 tahap yaitu sensorimotor dan praoperasional. Kedua tahap ini akan mengandalkan indera sebagai reseptor utama memperoleh 
pengalaman baru. tahap ini dikenal sebagai tahap egosentris dimana pemahaman dunia dilakukan melalui sesuatu yang konkret dan mementingkan diri sendiri (Hurlock, 2000).

Selain Piaget, ilmuan berikutnya yangjuga berkontribusi dengan memberi pandangan terkait perkembangan kognitif anak usia dini ialah Vygotsky. Vygotsky berpandangan bahwa sistem sosial yang berada di sekitar anak(orang tua,keluarga besar, guru dan teman sebaya)merupakan komponen penting dalam perkembangan kognitif anak. Sebutan zone of proximal development (ZPD) yang diartikan sebagai wilayah potensial anak untuk diberi pengajaran atau meningkatkan kemampuan anak memerlukan bantuan/scaffolding dari orang sekitarnya (Hurlock, 2000). Kedua tokoh merujuk padapenting keterlibatan orang tua dan pendidik untuk memberikan stimulasi pada anak usia dini agar perkembangan kognitif anak sesuai dengan tahap usia dan kemampuannya.

Pembelajaran sains memberikan pengaruh besar pada peningkatan perkembangan kognitif, bahasa, sosial emosional, motorik dan moral. Namun dari ke lima aspek perkembangan tersebut, kecenderungan yang dominan ialah pada perkembangan kognitif anak. Hal ini disebabkan karna pembelajaran dengan menggunakan pendekatan sains pada anak memiliki fungsi penting antara lain melatih anak untuk menghubungkan antara pengetahuan dan pengalaman. Science is not just learning fact (bukan hanya belajar fakta) and memorizing formula(mengingat rumus)tapi Science is problem solving sehingga dalam setiap prosesnya memiliki kebermaknaan dalam menguasai konsep(Klimer and Hofman dalam Woolfolk, 2009).Pembelajaran dengan menggunakan pendekatan sains untuk meningkatkan kemampuan kognitif pada anak usia dini karena dirancang sesuai dengan perkembangan berpikirnya.

Kemampuan kognitif yang meningkat yaitu kemampuan berfikir kritis, kemampuan berfikir logis, peningkatan kreativitas, kemampuan literasi sains, dan kemampuan pemecahan masalah. Pada pembelajaran sains di taman kanak-kanak, anak diharapkan mampu memenuhi capaian kurikulum. Menurut Permendikbud Indonesia Nomor 137 tahun 2014ada 3 indikator perkembangan kognitif yaitu;(1)berpikir logis, diantaranya; mengenal konsep besar-kecil, banyak-sedikit, panjang-pendek, berat-ringan, tinggi-rendah dengan menggunakan alat ukur yang tidak baku; mengenal sebab akibat dari peristiwa yang diamati (misalnya; energi panas dari matahari dapat mengeringkan baju yang dijemur) (2) Berpikir simbolik seperti mempresentasikan berbagai macam benda dalam bentuk gambar atau tulisan (3)belajar dan pemecahan masalah, diantaranya; anak menunjukkan kegiatan eksploratif dan menyelidik (misalnya, apa yang terjadi ketika air masukan di dalam lemari es, balon ditiupkan udara, api yang padam karna disiram air); menyesuaikan pengetahuan dan pengalaman yang ada ke dalam situasi baru; serta menemukan solusi dan menyelesaikan masalah dengan cara kreatif.

Maka dari itu, pengenalan sains untuk anak TK jika dilakukan dengan benar akan mengembangkan secara bertahap kemampuan berpikir logis yang belum dimiliki anak. Kemampuan berpikir logis ini akan membawa nalar anak untuk terbiasa melakukan kegiatan sains secara terstruktur dan sistematis(Suyanto, 2005).

\section{Ranah Afektif}

Ranah afektif ialah ranah yang berkaitan dengan sikap dan nilai-nilai pada peserta didik. Ranah ini mencakup perilaku, perasaan, minat, emosi, dan nilai yang dialami anak ketika suatu stimulasi dilakukan. Pembelajaran sains mampu membentuk interaksi timbal balik antar guru dan anak serta membuka peluang bagi anak untuk semakin peka pada apapun yang ada disekitarnya. Pembelajaran sains membangkitkan minat dan couriosity anak ketika ada hal baru yang dipelajari. Selain itu sains juga melatih kepekaan anak terhadap alam sekitarnya. Anak lebih menghargai dan menumbuhakn rasa cinta lingkungan. Mewujudkannya dalam tindakan menghargai dan melindungi alam (Olcer, 2017).

Tujuan utama pembelajaran sains anak usia dini ialah (1) agar anak terbiasa menggunakan metode saintifik untuk memecahkan masalah yang dihadapi, (2) agar 
terbentuk sikap ilmiah sejak dini, (3) agar anak memperoleh pengetahuan dan informasi ilmiah, (4)agar anak memiliki minat dan ketertarikan untuk menghayati sains yang berada dilingkungan. Seperti pada aktivitas mengamati; anak belajar untuk bersikap tenang dan fokus, aktivitas mengelompokkan; anak belajar memilah dan menentukan pilihan, aktivitas membuat prediksi; anak belajar menggunakan afeksinya dengan imajinasinya, melakukan percobaan; anak belajar untuk percaya diri dan bertanggung jawab untuk menuntaskan percobaannya dan aktivitas terakhir mengkomunikasikan yaitu anak belajar mengolah rasa menjadi sebuah bahasa yang menjadi representasi dari pengetahuannya. (Nugraha, 2008).

Selama proses pembela-jaran, anak sangat antusias, berse-mangat, dan serius dalam melakukan aktivitas-aktivitas setiap pertemu-annya. anak juga merasa senang, bergembira, dan tidak bosan dengan pembelajaran yang dilakukan oleh guru. Anak mempunyai keberanian dalam menjawab perta-nyaan dari guru, berani membacakan hasil karyanya di depan kelas, dan berani bertanya dengan temannya ketika diminta oleh guru. Anak juga dapat bersabar menunggu giliran selama proses pembelajaran.

Namun diantara ranah afektif yang terbentuk masih ada misidentified yang dialami anak mengenai konsep sains. Sebab children typically stated that they had learned very little sciencecontent and process (Mantzicopoulos et al., 2013). Hasil penelitian ((Mantzicopoulos et al., 2009);(Patrick \& Mantzicopoulos, 2015)) menemukan bahwa Activities they misidentifi ed as science include art, music, language arts, or math, as illustrated in the following quotes:

We color. We write our names. We write stuff. Bugs. We just color them in, that's all. (What do you learn?) About books. (What kinds of books?) "Sam I am" [i.e., a Dr. Seuss fictional book]. That's all. Learning to make stuff. (Like what?) Dolphins, whales, the boat, alligators, sharks. (What do you do in science?) We kind of make them with paper and and we paint them. We sing thealphabet. We do math .

Hal diatas menjelaskan bahwa ketika anak ditanya aktivitas sains apa yang telah anak lakukan, anak menjawab bahwa mereka mewarnai, menulis nama, membaca buku, membuat barang-barang seperti lumba-lumba, paus, buaya, perahu, hiu. Mereka membuatnya dengan kertas dan melukisnya. Lalu mereka bernyanyi dan melakukan kegiatan matematis. Padahal didalam kegiatan-kegiatan tersebut sains sudah dileburkan bersama kegiatan seni seperti mencampur warna, music, matematik dan lain sebagainya. Hingga saat ini, masih terbatas kajian yang mendalam mengenai pembelajaran sains sebagai stimulasi aspek sosial emosional, bahasa, seni dan aspek lainnya.

\section{Ranah Psikomotorik}

Ranah psikomotorik meliputi kemampuan melakukan sesuatu menggunakan keterampilan motorik, keterampilan sosial, dan keterampilan intelektual. Pada domain yang dikembangkan oleh Simpson ini ada 3 Klasifikasi ranah psikomotorik yang berkembang pada saat pembelajaran sains diberikan yaitu persepsi, kesiapan fisik mental dan emosional anak, respon tampak dan adaptasi.

Pembelajaran sains yang dilakukan oleh guru raya-rata telah menerapkan kompetensi inti dengan tahapan-tahapan pendekatan saintifik seperti; mengamati dengan indera, menanya, mengumpulkan informasi, menalar, dan mengomunikasikan (Permendikbud Indonesia Nomor 146, 2014). Pada tiap tahapannya anak menggunakan alat inderanya untuk membetuk sebuah persepsi mengenai konsep sains. Misalnya pada kegiatan percobaan sains tentang "hujan warna", Alat dan bahan yang dibutuhkan, seperti; gelas transparan, minyak goreng, pewarna alami, air dan sendok. Anak memulai investigasi menggunakan indera peraba (jari-jari tangan). Merasakan perbedaan masing-masing benda cair seperti air, minyak goreng, dan pewarna makanan. Selanjutnya anak menggunakan indera penciuman untuk membedakan macam-macam bau dari benda cair tersebut. Pada kegiatan ini guru tidak memasukan muatan investigasi menggunakan indera pengecap (lidah) dan indera pendengaran karena tidak ada esensi untuk itu. Dan terakhir anak mengamati macam-macam 
perubahan warna yang terbentuk di dalam gelas.Pada prosesnya anak mengkoordinasikan motorik halusnya untuk memasukan air dan minyak secara perlahan, meneteskan pewarna makanan. Dan menunggu reaksi perobaan dengan sabar.

Kesiapan anak secara fisik, mental dan emosional dibentuk selama pembelajaran sains. Melalui kegiatan sains di sekolah, serta pengelolaan lingkungan main yang aman dan nyaman menciptakan ruang bagi anak untuk menyelidiki, mengaktifkan panca inderanya, belajar membuat hipotesis dan mengungkapkan hasil temuannya menggunakan bahasanya sendiri. Kegiatan tersebut bermuara pada terbangunnya kesiapan anak dan literasi sains anak untuk jenjang pendidikan selanjutnya. Nantinya anak memiliki rasa ingin tahu yang tinggi serta penalaran yang luas (high order thingking) (Dogan \& Simsar, 2018).

\section{SIMPULAN}

Maka disimpulkan bahwa pola pembelajaran sains ditaman kanak-kanak dominan menggunakan pola pembelajaran indirect instruction daripada pola pembelajaran direct instruction. Dimana guru tidak dominan namun hanya berperan sebagai fasilitator awal untuk menstimulus respon berfikir anak. Berdasarkan hasil stimulasi pada tiap-tiap jurnal menunjukkan adanya peningkatan kemampuan pada anak usia dini khususnya ranah kognitif, lalu diikuti afektif dan psikomotor. Metode pembelajaran sains melalui bermain sensormotorik, eksperimen dan bermain dengan media paling banyak digunakan untuk menstimulasi berbagai kemampuan anak. Sangat disarankan kepada pihak sekolah untuk concern mengimplementasikan pembelajaran sains dalam melatih dan mengembangkan aspek perkembangan lain seperti moral agama, bahasa, dan seni.

\section{UCAPAN TERIMA KASIH}

Ucapan terima kasih disampaikan kepada Bapak Sugito selaku dosen mata kuliah Kajian Permasalahan PAUD di Pascasarjana Universitas Negeri Yogyakarta telah membekali pengetahuan dan memberi bimbingan kepada saya ketika proses penulisan jurnal dan Lembaga Pengelola Dana Pendidikan (LPDP) yang telah memberikan dukungan materil sehingga dapat terbitnya artikel ini.

\section{DAFTAR PUSTAKA}

Adbo, K., \& Carulla, C. V. (2020). Learning about science in preschool: play-based activities to support children's understanding of chemistry concepts. International Journal of Early Childhood, 52(1), 17-35. https:// doi.org/10.1007/s13158-020-00259-3

Aufan, A. M. A. (2011). The Effect of Direct Instruction Strategy on Math Achievement. International Journal of Education Studies, 4(4), 199-205.

Bennett, J. (2016). Bringing science to life: Research evidence. In Teachers creating contextbased learning environments in science (pp. 19-39). Brill Sense. https:// doi.org/10.1002/sce.20186

Broström, S. (2015). Science in early childhood education. Journal of Education and Human Development, 4(2), 1. https:// doi.org/10.15640/jehd.v4n2_1a12

Dewi, A. C., Hapidin, H., \& Akbar, Z. (2019). Pengaruh Model Pembelajaran dan Kemampuan Berpikir Kritis terhadap Pemahaman Sains Fisik. Jurnal Obsesi: Jurnal Pendidikan Anak Usia Dini, 3(1), 18-29. https://doi.org/10.31004/obsesi.v3i1.136

Dogan, Y., \& Simsar, A. (2018). Preschool Teachers' Views on Science Education, the Methods They Use, Science Activities, and the Problems They Face. International Journal of Progressive Education, 14(5), 57-76. https:// doi.org/10.29329/ijpe.2018.157.6

Dwirahmah, E. (2013). Peningkatan Kreativitas Melalui Pendekatan Inquiri dalam Pembelajaran Sains. Jurnal Pendidikan Usia Dini, 7(2), 240-250. https:// doi.org/10.21009/Jpud.072.04 
Fardiah, F., Murwani, S., \& Dhieni, N. (2019). Meningkatkan Kemampuan Kognitif Anak Usia Dini melalui Pembelajaran Sains. Jurnal Obsesi: Jurnal Pendidikan Anak Usia Dini, 4(1), 133-140. https://doi.org/10.31004/obsesi.v4i1.254

Guo, Y., Piasta, S. B., \& Bowles, R. P. (2015). Exploring preschool children's science content knowledge. Early Education and Development, 26(1), 125-146. https://doi.org/10.1080/10409289.2015.968240

Howitt, C., Lewis, S., \& Upson, E. (2011). 'It's a Mystery': A Case Study of Implementing Forensic Science in Preschool as Scientific Inquiry. Australasian Journal of Early Childhood, 36(3), 45-55. https:// doi.org/10.1177/183693911103600307

Hurlock, E. B. (2000). Perkembangan anak jilid 1 edisi 6. Jakarta: Erlangga.

Joyce, D. (2009). Models Of Teaching. Jogjakarta: Pustaka Belajar.

Kang, J., Liu, M., \& Qu, W. (2017). Using gameplay data to examine learning behavior patterns in a serious game. Computers in Human Behavior, 72, 757-770. https://doi.org/10.1016/j.chb.2016.09.062

Khaeriyah, E., Saripudin, A., \& Kartiyawati, R. (2018). Penerapan metode eksperimen dalam pembelajaran sains untuk meningkatkan kemampuan kognitif anak usia dini. AWLADY: Jurnal Pendidikan Anak, 4(2), 102-119. https://doi.org/10.24235/awlady.v4i2.3155

Levy, S. T. (2013). Young children's learning of water physics by constructing working systems. International Journal of Technology and Design Education, 23(3), 537-566. https://doi.org/10.1007/s10798-012-9202-z

Magasida, D. (2017). Penerapan Metode Discovery Inkuiri Pada Pembelajaran Sains Anak Usia Dini. AWLADY: Jurnal Pendidikan Anak, 3(1). https:// doi.org/10.24235/awlady.v3i1.1395

Mantzicopoulos, P., Patrick, H., \& Samarapungavan, A. (2013). Science literacy in school and home contexts: Kindergarteners' science achievement and motivation. Cognition and Instruction, 31(1), 62-119. https:// doi.org/10.1080/07370008.2012.742087

Mantzicopoulos, P., Samarapungavan, A., \& Patrick, H. (2009). "We learn how to predict and be a scientist": Early science experiences and kindergarten children's social meanings about science. Cognition and Instruction, 27(4), 312-369. https://doi.org/10.1080/07370000903221726

Mustika, Y., \& Nurwidaningsih, L. (2018). Pengaruh Percobaan Sains Anak Usia Dini terhadap Perkembangan Kognitif Anak di TK Kartika Siwi Pusdikpal Kota Cimahi. Jurnal Obsesi: Jurnal Pendidikan Anak Usia Dini, 2(1), 94-101. https://doi.org/10.31004/obsesi.v2i1.12

Nazir, M. (2014). Metode Penelitian [Research Methods]. Bogor: Ghalia Indonesia.

Nirmala, B. (2014). Peningkatan Hasil Belajar Sains Melalui Science Process Skills Approach. Jurnal Pendidikan Usia Dini, 8(2), 231-240. https:/ / doi.org /10.21009/Jpud.082.04

Noor, F. M. (2020). Memperkenalkan Literasi Sains Kepada Peserta Didik: Perspektif Calon Guru PIAUD. ThufuLA: Jurnal Inovasi Pendidikan Guru Raudhatul Athfal, 8(1), 056. https://doi.org/10.21043/thufula.v8i1.7066

Nugraha, A. (2008). Pengembangan Sains Pada Anak Usia Dini. Bandung: Jilsi Foundation Pembelajaran.

OECD. (2018). PISA 2015. PISA Result in Focus. Retrieved from https://www.oecd.org/pisa/publications/pisa-\%0A2018-results.htm

Olcer, S. (2017). Science Content Knowledge of 5-6 Year Old Preschool Children. International Journal of Environmental and Science Education, 12(2), 143-175.

Patrick, H., \& Mantzicopoulos, P. (2015). Young children's motivation for learning science. In Research in early childhood science education (pp. 7-34). Springer. https://doi.org/10.1007/978-94-017-9505-0_2

Permendikbud Indonesia Nomor 146. (2014). Kurikulum 2013 Pendidikan Anak Usia Dini. Jakarta: Menteri Pendidikan. 
Poppyariyana, A. A., \& Munajat, A. (2020). Pengaruh Permainan Sains Terhadap Kemampuan Berpikir Logis Anak. Awlady: Jurnal Pendidikan Anak, 6(1), 1-16. https:// doi.org/10.24235/awlady.v6i1.5779

Rahmah, R. (2019). Persepsi Guru Tentang Pembelajaran Sains Anak Usia 5-6 Tahun di Gugus II Melati Kecamatan Simpang Tiga Pekanbaru. KINDERGARTEN: Journal of Islamic Early Childhood Education, $\quad 1(2), \quad$ 89-101. https:// doi.org/10.24014/kjiece.v1i2.6656

ahmawati, N. (2018). Pengembangan Alat Permainan Edukatif Dalam Pembelajaran Bahasa Arab Di Madrasah Ibtidaiyah Wahid Hasyim Sleman Yogyakarta. Lisan Al-Arab: Journal of Arabic Language And Arabic Teaching, 7(1), 37-44. https://doi.org/ 10.15294/la.v7i1.26072

Saepudin, A. (2011). Pembelajaran Sains Pada Program Pendidikan Anak Usia Dini. Jurnal Teknodik, XV(2), 213-226.

Sanjaya, W. (2007). Buku Materi Pokok: Kajian Kurikulum dan Pembelajaran. Bandung: Sekolah Pasca Sarjana Universitas Pendidikan Indonesia.

Santrock, J. W. (2007). Perkembangan Anak. 11h Edition. Jakarta: Erlangga.

Smolleck, L. (2011). Playing with science: An investigation of young children's science conceptions and misconceptions. Current Issues in Education, 14(1).

Suyanto, S. (2005). Dasar-dasar pendidikan anak usia dini. Yogyakarta: Hikayat Publishing.

Tatminingsih, S. (2019). Alternatif Stimulasi Kemampuan Kognitif melalui Penerapan Model Pembelajaran Berbasis Permainan Komprehensif. Jurnal Obsesi: Jurnal Pendidikan Anak Usia Dini, 3(1), 183-190. https:// doi.org/10.31004/obsesi.v3i1.130

Tohir, M. (2019). Hasil PISA Indonesia Tahun 2018 Turun Dibanding Tahun 2015. 2018-2019. https:// doi.org/10.31219/osf.io/pcjvx

UNEP. (2012). 21 Issues for the 21st Century: Result of the UNEP Foresight Process on Emerging Environmental Issues. In Environmental Development (Vol. 2). https:// doi.org/10.1016/j.envdev.2012.03.005

Watanabe, M., McLaughlin, T. F., Weber, K. P., \& Shank, L. (2013). The effects of using direct instruction to teach coin counting and giving change with a young adult: A case report. International Journal of Basic and Applied Science, 2(1), 150-159.

Widayati, J. R., Safrina, R., \& Supriyati, Y. (2020). Analisis Pengembangan Literasi Sains Anak Usia Dini melalui Alat Permainan Edukatif. Jurnal Obsesi: Jurnal Pendidikan Anak Usia Dini, 5(1), 654-664. https:// doi.org/10.31004/obsesi.v5i1.692

Widiyatmoko, A., \& Shimizu, K. (2018). An overview of conceptual understanding in science education curriculum in Indonesia. Journal of Physics: Conference Series, 983(1), 12044. https:// doi.org/10.1088/1742-6596/983/1/012044

Witarsa, R., \& Dista, D. X. (2019). Analisis Jawaban Siswa Usia 6 sampai 8 tahun terhadap Pembelajaran Sains Kreatif. Jurnal Obsesi: Jurnal Pendidikan Anak Usia Dini, 4(1), 5866. https:// doi.org/10.31004/obsesi.v4i1.288

Woolfolk, A. (2009). Educational Psychology Active Learning Edition. Jakarta: Pustaka Pelajar.

Yunansah, H. (2014). Fenomena Fisika Dalam Mengembangkan Keterampilan Sains Anak Usia Dini. Cakrawala Dini: Jurnal Pendidikan Anak Usia Dini, 5(2). https:// doi.org/10.17509/cd.v5i2.10504

Zulaiha, D., \& Rohman, A. (2020). Strategi Guru dan Keterlibatan Orangtua dalam Pemahaman Konsep Sains Anak Selama Covid-19. Jurnal Obsesi: Jurnal Pendidikan Anak Usia Dini, 5(2), 1248-1260. https://doi.org/10.31004/obsesi.v5i2.816 


\section{Lampiran 1}

Tabel 1. Detail Literatur yang diteliti

\begin{tabular}{|c|c|c|c|}
\hline $\begin{array}{c}\text { Penulis dan } \\
\text { tahun }\end{array}$ & $\begin{array}{c}\text { Metode } \\
\text { Penelitian }\end{array}$ & $\begin{array}{l}\text { Klasifikasi } \\
\text { pola }\end{array}$ & Hasil utama \\
\hline $\begin{array}{l}\text { (Mustika \& } \\
\text { Nurwidaningsih, } \\
2018 \text { ) }\end{array}$ & $\begin{array}{l}\text { Metode } \\
\text { penelitian } \\
\text { eksperimen }\end{array}$ & Pola direct & $\begin{array}{l}\text { Bentuk Pembelajaran : Eksplorasi Langsung } \\
\text { Metode : Metode percobaan diawali demonstrasi guru dan } \\
\text { guru bertanya } \\
\text { Media : Air, Pewarna Makanan } \\
\text { Pengelolaan Kelas : Indoor Learning } \\
\text { Terjadi peningkatan kemampuan kognitif sisa/siswi TK } \\
\text { Kartika Siwi Pusdikpal Cimahi setelah melakukan percobaan } \\
\text { sains sederhana pada materi mencampur warna. }\end{array}$ \\
\hline $\begin{array}{l}\text { (Zulaiha \& } \\
\text { Rohman, 2020) }\end{array}$ & $\begin{array}{l}\text { metode survei, } \\
\text { pendekatan } \\
\text { deskriptif } \\
\text { kuantitatif. }\end{array}$ & Pola direct & $\begin{array}{l}\text { Bentuk Pembelajaran : Intruksional (mengikuti tutorial video) } \\
\text { Metode : Percobaan sederhana } \\
\text { Media : air, piring, lada, dan sabun cuci piring } \\
\text { Pengelolaan Kelas : Learning by Home (dibimbing orang tua) } \\
\text { Adanya perkembangan pada akemampuan pemahaman } \\
\text { konsep sains pada siswa TK Islam Al-Azhar } 41 \text {. }\end{array}$ \\
\hline $\begin{array}{l}\text { (Fardiah et al., } \\
\text { 2019) }\end{array}$ & $\begin{array}{l}\text { Metode } \\
\text { tindakan kelas, } \\
\text { pendekatan } \\
\text { deskriptif } \\
\text { analisis }\end{array}$ & $\begin{array}{l}\text { Pola } \\
\text { Indirect }\end{array}$ & $\begin{array}{l}\text { Bentuk pembelajaran : bermain sensori } \\
\text { Metode : pengamatan langsung } \\
\text { Media : sayur-sayuran } \\
\text { Pengelolaan kelas : Indoor Learning } \\
\text { hasil penelitian ditemukan ada peningkatan kemampuan } \\
\text { kognitif siswa kelas B di PAUD Cikal Harapan } 4 \text { Depok, Jawa } \\
\text { Barat setelag bermain sensori sains }\end{array}$ \\
\hline $\begin{array}{l}\text { (Witarsa \& Dista, } \\
\text { 2019) }\end{array}$ & $\begin{array}{l}\text { metode } \\
\text { penelitian } \\
\text { deskriptif } \\
\text { kuantitatif }\end{array}$ & Pola Direct & $\begin{array}{l}\text { Bentuk pembelajaran : sains kreatif } \\
\text { Metode : tanya jawab } \\
\text { Media : lembar kerja } \\
\text { Pengelolaan kelas : Indoor Learning } \\
\text { Adanya perkembangan pada aspek kreatif secara terstruktur } \\
\text { pada siswa sekolah dasar kelas rendah. }\end{array}$ \\
\hline
\end{tabular}

\begin{tabular}{|c|c|c|c|}
\hline $\begin{array}{l}\text { (Dewi et al., } \\
\text { 2019) }\end{array}$ & $\begin{array}{l}\text { Metode } \\
\text { eksperimen } \\
\text { tipe treatment } \\
\text { by level } 2 \times 2\end{array}$ & $\begin{array}{l}\text { Pola } \\
\text { indirect }\end{array}$ & $\begin{array}{l}\text { Bentuk pembelajaran : model quantum dan model CTL } \\
\text { (contextual teaching and learning) } \\
\text { Metode : "TANDUR" (Tumbuhkan, Alami, Namai, } \\
\text { Demontrasikan, Ulangi dan Rayakan) } \\
\text { Media : musik, merayakan belajar, dan mengatur lingkungan } \\
\text { belajar } \\
\text { Pengelolaan kelas : indoor learning } \\
\text { Hasil menunjukkan adanya peningkatan critical thingking skills } \\
\text { anak khususnya pemahaman sains fisika setelah diterapkan } \\
\text { kedua model tersebut }\end{array}$ \\
\hline $\begin{array}{l}\text { (Widayati et al., } \\
\text { 2020) }\end{array}$ & $\begin{array}{l}\text { metode analisis } \\
\text { konten dengan } \\
\text { pendekatan } \\
\text { kualitatif }\end{array}$ & $\begin{array}{l}\text { Pola } \\
\text { Indirect }\end{array}$ & $\begin{array}{l}\text { Bentuk Pembelajaran : Eksplorasi Langsung } \\
\text { Metode : Praktek langsung } \\
\text { Media : bunyi-bunyian pipa, alat dapur, lantai, kayu dll } \\
\text { Pengelolaan Kelas : Indoor Outdoor Learning } \\
\text { Kemampuan literasi sains meningkat dengan penggunaan } \\
\text { alat permainan edukatif }\end{array}$ \\
\hline (Nirmala, 2014) & $\begin{array}{l}\text { Metode } \\
\text { penelitian } \\
\text { tindakan kelas, } \\
\text { pendekatan } \\
\text { kuantitatif dan } \\
\text { kualitatif }\end{array}$ & Pola Direct & $\begin{array}{l}\text { Bentuk Pembelajaran : Science Process Skills Approach } \\
\text { Metode : Scientific } \\
\text { Pengelolaan Kelas : Indoor outdoor learning } \\
\text { penggunaan pendekatan keterampilan proses sains dapat } \\
\text { meningkatkan hasil belajar siswa SD kelas rendah pada } \\
\text { seluruh ranah yaitu ranah kognitif, afektif, dan psikomotorik. }\end{array}$ \\
\hline $\begin{array}{l}\text { (Dwirahmah, } \\
\text { 2013) }\end{array}$ & $\begin{array}{l}\text { metode } \\
\text { penelitian } \\
\text { tindakan, } \\
\text { analisis } \\
\text { statistik } \\
\text { deskriptif }\end{array}$ & $\begin{array}{l}\text { Pola } \\
\text { indirect }\end{array}$ & $\begin{array}{l}\text { Bentuk Pembelajaran : model inquiri } \\
\text { Metode : bermain } \\
\text { Media : tanah liat, plastisin dan menggambar } \\
\text { Pengelolaan Kelas : outdoor learning } \\
\text { adanya kenaikan rerata skor kreativitas yang diperoleh anak } \\
\text { setelah pembelajaran sains dengan pendekatan inquiry }\end{array}$ \\
\hline (Magasida, 2017) & $\begin{array}{l}\text { Metode } \\
\text { pengembangan }\end{array}$ & Pola direct & $\begin{array}{l}\text { Bentuk Pembelajaran : model inquiri Discovery } \\
\text { Metode : penyelidikan }\end{array}$ \\
\hline
\end{tabular}




\begin{tabular}{|c|c|c|c|}
\hline $\begin{array}{c}\text { Penulis dan } \\
\text { tahun }\end{array}$ & $\begin{array}{c}\text { Metode } \\
\text { Penelitian }\end{array}$ & $\begin{array}{c}\text { Klasifikasi } \\
\text { pola }\end{array}$ & Hasil utama \\
\hline & & & $\begin{array}{l}\text { Media : bahan-bahan terdekat anak } \\
\text { Pengelolaan Kelas : indoor learning } \\
\text { Penerapan Sains mampu meningkatkan kemampuan berfikir } \\
\text { kritis }\end{array}$ \\
\hline $\begin{array}{l}\text { (Poppyariyana \& } \\
\text { Munajat, 2020) }\end{array}$ & $\begin{array}{l}\text { Penelitian } \\
\text { Kuasi } \\
\text { Eksperimen }\end{array}$ & $\begin{array}{l}\text { Pola } \\
\text { Indirect }\end{array}$ & $\begin{array}{l}\text { Bentuk Pembelajaran : Eksplorasi terbimbing } \\
\text { Metode : Permainan Sains } \\
\text { Media : Benda Terapung, Benda Tenggelam, Benda Yang } \\
\text { Mudah Terbakar, Balon Udara } \\
\text { Pengelolaan Kelas : Outdoor Learning } \\
\text { permainan sains dapat berpengaruh kemampuan berpikir } \\
\text { logis anak. }\end{array}$ \\
\hline $\begin{array}{l}\text { (Khaeriyah et al., } \\
\text { 2018) }\end{array}$ & $\begin{array}{l}\text { penelitian } \\
\text { tindakan kelas, } \\
\text { analisis } \\
\text { deskriptif } \\
\text { kualitatif dan } \\
\text { kuantitatif. }\end{array}$ & Pola Direct & $\begin{array}{l}\text { Bentuk Pembelajaran : Eksplorasi terbimbing } \\
\text { Metode : eksperimen } \\
\text { Media : pengenalan warna, pencampuran warna, pengenalan } \\
\text { tumbuhan, pengenalan binatang, serta mengenal gejala-gejala } \\
\text { alam } \\
\text { Pengelolaan Kelas : Indoor Outdoor Learning } \\
\text { penggunaan metode eksperimen dalam pembelajaran saisn } \\
\text { dapat meningkatkan kemampuan kognitif pada anak usia } \\
\text { dini. }\end{array}$ \\
\hline (Yunansah, 2014) & $\begin{array}{l}\text { Deskriptif } \\
\text { kualitatif }\end{array}$ & $\begin{array}{l}\text { Pola } \\
\text { Indirect }\end{array}$ & $\begin{array}{l}\text { Bentuk pembelajaran : Pembelajaran Kontekstual } \\
\text { Metode : pengamatan langsung } \\
\text { Media : benda padat, mengenal gerak benda, mengenal benda } \\
\text { cair, mengenal sifat terapung dan tenggelam, mengenal } \\
\text { warna, mengenal benda elastis, mengenal udara, mengenal } \\
\text { bayang-bayang, mengenal neraca, mengenal api, mengenal es, } \\
\text { mengenal bunyi, serta mengenal benda magnet. } \\
\text { Pengelolaan Kelas : Indoor Outdoor Learning } \\
\text { Pembelajaran menggunakan kontekstual mampu } \\
\text { meningkatkan keterampilan sains anak }\end{array}$ \\
\hline (Rahmah, 2019) & $\begin{array}{l}\text { metode } \\
\text { deskriptif } \\
\text { kualitatif, }\end{array}$ & Pola Direct & $\begin{array}{l}\text { Bentuk Pembelajaran : Praktek Langsung } \\
\text { Metode : Pengamatan objek langsung atau gambar } \\
\text { Media : Tumbuhan dan binatang } \\
\text { Pengelolaan kelas : indoor outdoor } \\
\text { Sains mengembangkan intelektual,emosional dan fisik } \\
\text { jasmani atau aspek kognitif, afektif dan psikomotorik anak }\end{array}$ \\
\hline
\end{tabular}

\begin{tabular}{|c|c|c|c|}
\hline \multicolumn{4}{|c|}{ International Journal (Tambahan) } \\
\hline $\begin{array}{l}\text { (Howitt et al., } \\
2011)\end{array}$ & $\begin{array}{l}\text { A qualitative } \\
\text { case } \quad \text { study } \\
\text { research design }\end{array}$ & $\begin{array}{l}\text { Pola } \\
\text { Indirect }\end{array}$ & $\begin{array}{l}\text { Bentuk Pembelajaran : inquiry and project-based learning } \\
\text { Metode : Penyelidikan dan Forensic science method } \\
\text { Media : fingerprints as loops, hair,whorls or arches. } \\
\text { Pengelolaan kelas : indoor outdoor } \\
\text { the forensic science bear hunt context } \\
\text { provided opportunities for the children to extend their } \\
\text { imagination, develop their oral language, and act like } \\
\text { scientists. (Forensic Sains bisa meningkatkan kemampuan } \\
\text { imajinasi, oral language, dan act) }\end{array}$ \\
\hline (Levy, 2013) & Eksperimen & $\begin{array}{l}\text { Pola } \\
\text { Indirect }\end{array}$ & $\begin{array}{l}\text { Bentuk Pembelajaran : Eksperimen } \\
\text { Metode : bermain pembangunan } \\
\text { Media : Toolbox dan water sistem } \\
\text { Pengelolaan kelas : indoor outdoor learning } \\
\text { group developed significantly better understandings about } \\
\text { water flow after engaging in a series of building activities }\end{array}$ \\
\hline
\end{tabular}

